\title{
Crop Productivity and Soil Biological Properties Influenced by Long Term Application of Mineral Fertilizers and Manures under Rice-Wheat Sequence on Mollisols of Northern India
}

\author{
Vineet Kumar*, Shri Ram and Ramesh Chandra
}

Department of Soil Science, G. B. Pant University of Agriculture and Technology, Pantnagar- 263145 Uttarakhand, India

*Corresponding author

\begin{abstract}
A B S T R A C T
\section{Keywords}

Crop productivity,

Fertilizers,

Manures,

Rice-Wheat

Sequence, Mollisols

Article Info

Accepted:

04 August 2019

Available Online:

10 September 2019

The rice-wheat cropping system, which is considered as the backbone of food selfsufficiency, is facing a sustainability problem due to practices of modern production system with indiscriminate use of chemical fertilizers and pesticides. So, effects of long term use of mineral fertilizers and farmyard manure (FYM) under rice (Oryza sativa)wheat (Triticum aestivum) cropping system in a Mollisol was investigated. Rice and wheat yields were highest (51.47 and $48.60 \mathrm{q} \mathrm{ha}^{-1}$, respectively) with $100 \% \mathrm{NPK}+15 \mathrm{t}$ FYM $\mathrm{ha}^{-1}$ and lowest in control (13.72 and $11.85 \mathrm{q} \mathrm{ha}^{-1}$, respectively). Balanced fertilizers use of $(100 \%$ NPK + Zn) was also at par with $100 \%$ NPK + FYM treatment in rice and wheat yields. The FYM amended treatment gave the highest and significantly more counts of bacteria, fungi and actinomycetes in all four depths of soil $(0-15 \mathrm{~cm}, 15-30 \mathrm{~cm}, 30-45 \mathrm{~cm}$ and $45-60 \mathrm{~cm})$ as compared to all other treatments after crop harvest. The observed microbial biomass C with 100\% NPK + FYM in four soil depths were (413.36, 193.50, 100.11 and 66.41 after rice and 435.93, 235.54, 142.64 and $82.41 \mu \mathrm{g} \mathrm{g}^{-1}$ after wheat, respectively, which was highest and significantly higher over all other treatments. Soil enzymes dehydrogenase, acid and alkaline phosphatase and urease activities were significantly higher with $100 \% \mathrm{NPK}+15 \mathrm{t} \mathrm{FYM} \mathrm{ha}^{-1}$ than all the other treatments. Mineral fertilizer treatments with $100 \%$ NPK and $150 \%$ NPK were comparable and significantly better than application of $50 \%$ NPK, $100 \% \mathrm{~N}$ and $100 \% \mathrm{NP}$ in different soil biological properties. Application of $\mathrm{Zn}$ with $100 \%$ NPK increased the crop yields and soil biological properties over $100 \%$ NPK. Imbalanced use of mineral fertilizers had the harmful effect on soil biological health.
\end{abstract}

\section{Introduction}

The rice (Oryza sativa L.) - wheat (Triticum aestivum $\mathrm{L}$.) cropping system occupies about 28.8 million hectares mainly spread over Asia's five countries, namely, India, Pakistan, Nepal, Bangladesh and China (Timsinia and
Connor, 2001; Prasad, 2005). Rice-wheat cropping system followed in Indo-Gangatic plains of India is also a main cropping system of newly carved Uttarakhand state. This signifies the contribution of rice-wheat cropping system in meeting food requirements of the country. The rice-wheat cropping 
system, which is considered as the backbone of food self-sufficiency, is however facing a sustainability problem due to practices of modern production system with indiscriminate use of chemical fertilizers and pesticides (Duxbury et al., 2000; Ladha et al., 2000; Prasad, 2005). The production of both these crops has increased remarkably with the development of high-yielding and fertilizer responsive crop varieties (Ram et al., 2011). The rice-wheat cropping system is highly nutrient exhaustive and annually removes about $650 \mathrm{~kg} \mathrm{~N}, \mathrm{P}$ and $\mathrm{K} \mathrm{ha}^{-1}$ and $0.5-1.0 \mathrm{~kg}$ $\mathrm{ha}^{-1} \mathrm{Zn}$ (Shah et al., 2011). This has led to a noticeable increase in fertilizer use in these crops; about $65 \%$ of the total fertilizer consumed in India for these two crops (Yadav and Kumar, 2009). According to Ladha et al., (2003) and Manna et al., (2005), fertilizer consumption in the country is on the rise, the productivity of rice and wheat crops started showing fatigue at many locations in this cropping system. The stagnation and declining trends in yields in the rice-wheat cropping system in Asia have been reported to be mainly due to over-exploitation of soils, imbalanced use of plant nutrients (Yadav et al., 2000) and deterioration in soil physical conditions. Several workers have reported the benefit of organic manure in improving and sustaining the production of rice-wheat system. Farmyard manure is house hold organic manure obtain due to microbial activity and contains large number of microbial population. Application of farm yard manure can increase the microbial activity in the soil both by activating the microbial activity through supplying $\mathrm{C}$ and nutrients to heterotrophic microorganisms (Gaur et al., 1990). There are some indications that integrated use of organic and inorganic fertilizer improves biological properties of soil (Ram et al., 2015). Large numbers of report are available in the literature to show the enhanced microbial activity by application of farmyard manure (Bhatt et al., 2016). There are very few studies on microbial population and enzymatic activities with respect to fertilizer and manure application. Therefore, this study was planned to find out the effect of long term application of fertilizer and manure on crop productivity microbial biomass and enzymatic activities of soil with rice-wheat cropping system on a Mollisols of Northern India.

\section{Materials and Methods}

\section{Experimental site}

The present study is apart of an ongoing longterm fertilizer experiment with a rice-wheat cropping system, was started with wet-season rice in 1971 at the Norman E. Borlaug Crop Research Centre of the Govind Ballabh Pant University of Agriculture and Technology, Pantnagar $\left(29^{\circ} \mathrm{N}, 79.3^{\circ} \mathrm{E}, 243.2 \mathrm{~m}\right.$ above sea level) located in the foothill soils of the tarai region of Udham Singh Nagar district of Uttrakhand, India. The experimental field was brought under the rice and wheat cultivation on a forested ecosystem. The mean annual rainfall is about $1400 \mathrm{~mm}$, of which $80-90 \%$ is received between June and September. Mean maximum and minimum temperatures ranged between 35 and $18{ }^{\circ} \mathrm{C}$ during rice and 25 and $2{ }^{\circ} \mathrm{C}$ during wheat crops, respectively. At the start of the experiment, the soil was poorly drained, and had high organic carbon, nitrogen, and zinc. The rainfall received during cropping period was $1116.3 \mathrm{~mm}$ in 2016-2017, the experimental soil was classified under sub-group Aquic hapludoll in order Mollisols (Deshpande et al., 1971). The soil had silty clay loam texture (sand: $32 \%$, silt: $39 \%$, clay: $29 \%$,), with $\mathrm{pH} 7.30$ and electrical conductivity $0.35 \mathrm{dS} \mathrm{m}^{-1}$ (in soil:water ratio of $1: 2.5)$, cation exchange capacity $20.0 \mathrm{cmol}(\mathrm{p}+) \mathrm{kg}^{-1}$, soil organic C $14.8 \mathrm{~g} \mathrm{~kg}^{-1}$, alkaline $\mathrm{KMnO}_{4}$ extractable $\mathrm{N}$ $392 \mathrm{~kg} \mathrm{ha}^{-1}, 0.5 \mathrm{M} \mathrm{NaHCO}_{3}$ extractable P 18 $\mathrm{kg} \mathrm{ha}^{-1}$ and $1 \mathrm{~N}$ ammonium acetate extractable $\mathrm{K} 125 \mathrm{~kg} \mathrm{ha}^{-1}$ (Ram, 1995). 


\section{Treatments details}

The nutrient treatments being used for rice and wheat crops since 1971 were T1 [50\% Nitrogen, Phosphorus, Potassium (NPK)], T2 $(100 \%$ NPK), T3 (150\% NPK), T4 [100\% NPK + Zinc (Zn)], T5 (100\% NP), T6 (100\% N), T7 (100\% NPK + farm yard manure (FYM)), T8 [100\% NPK - Sulphur (S)] and T9 (unfertilized control). The $100 \%$ NPK represents the recommended fertilizer doses for each crop as determined from soil tests in 1971. The treatments were laid out in a randomized block design with plots of $25 \mathrm{~m} \times$ $12 \mathrm{~m}$ size in four replications. Fertilizer doses and sources used at optimal NPK level (100\% NPK) based on initial soil tests were $120 \mathrm{~kg} \mathrm{~N}$ $\mathrm{ha}^{-1}$ through urea and diammonium phosphate (DAP), $26 \mathrm{~kg} \mathrm{P} \mathrm{ha}^{-1}$ through DAP and single superphosphate and $37 \mathrm{~kg} \mathrm{~K}$ ha-1 through muriate of potash. The single superphosphate was not used to avoid $\mathrm{S}$ for treatment $\mathrm{T} 8$. Treatment T7 (100\% NPK + FYM) received $15 \mathrm{t} \mathrm{FYM} \mathrm{ha}^{-1}(0.50-0.80 \% \mathrm{~N}, 0.26-0.30 \% \mathrm{P}$, $0.45-0.50 \% \mathrm{~K})$ in wheat before the preparation of field. It was mixed in plough layer of soil $(0-15 \mathrm{~cm})$ by tillage. Half dose of $\mathrm{N}$ and full dose of $\mathrm{P}$ and $\mathrm{K}$ were applied as basal at the time of sowing. The remaining half dose of $\mathrm{N}$ was applied in two equal splits after 25 and 50 days of transplanting in rice and 30 and 55 days after sowing in wheat. Since kharif, 1993, zinc was applied to rice as basal $50 \mathrm{~kg}$ zinc sulphate $\mathrm{ha}^{-1}(21.0 \% \mathrm{Zn})$ approximately at a gap of 4-5 years in treatment T1, T4, T5, T6 and T7 when $\mathrm{Zn}$ in soil becomes less than critical level $(<1.0$ ppm). In T4, Zn was also applied at the same rate as basal each year, Zinc in treatment $\mathrm{T} 8$ was applied as Zinc oxide $(\mathrm{ZnO})$ at the same rate. Weeds were controlled by chemically using butachlor in rice $(1.5 \mathrm{~kg}$ a.i. ha-1 at 2 days after transplanting) and pendimethaline in wheat (1.0 kg a.i. ha-1 as pre-emergence). Rice (cv. PR 113) and wheat (cv. PBW 502) were raised during the cropping season with recommended crop management practices. Irrigation was applied as per need of the field and rainfall activity. The harvested produce was sun dried for 3-4 days and weighed for recording biological yield. The grains were separated from the produce with mechanical thresher, cleaned, sun dried to approximately $12.0 \%$ moisture and weighed for recording grain yield. The straw yield was recorded by subtracting the grain yield from the biological yield.

\section{Soil sampling and laboratory analysis}

Soil samples from four depths $(0-15 \mathrm{~cm}, 15-30$ $\mathrm{cm}, 30-45 \mathrm{~cm}$ and $45-60 \mathrm{~cm}$ ) were collected with the help of auger from individual plots after the harvesting of rice and wheat crops. The field moist soil samples were sieved through $2 \mathrm{~mm}$ sieve and stored in plastic bags at $4^{\circ} \mathrm{C}$ in deep fridge. The population of bacteria, fungi and actinomycetes in soil was determined by serial dilution pour plate method using nutrient agar medium for bacteria, Ken Knight and Munaier's medium for actinomycetes and Martin's Rose-Bengal streptomycin agar medium for fungi (Wollum, 1982). Microbial biomass carbon (MBC) in soil samples were estimated following chloroform-fumigation-extraction procedure as described by Jenkinson and Powlson (1976) using Kc value of 0.45 for MBC (Vance et al., 1987). Soil dehydrogenase activity was determined by the reduction of 2,3,5triphenyl-tetrazolium chloride to 1,3,5triphenylformazan (TPF) by the method of Casida et al., (1964). The acid and alkaline phosphatase activities in soil were determined as per the method given by Tabatabai and Bremner (1969) by using p-nitrophenyl phosphate tetrahydrate solution of $\mathrm{pH} 6.5$ for acid phosphatase and $\mathrm{pH} 11.0$ for alkaline phosphatase enzymes. The urease enzyme activity was done by the estimation of urea hydrolysis as described by Tabatabai (1982). The obtained data on rice and wheat yields 
and soil biological properties of both the years were pooled and subjected to standard analysis of variance (ANOVA) following standard procedures for randomized block design (Gomez and Gomez 1984). Correlation study was done with the help of SPSS-16 statistical package (SPSS, Inc., Chicago, IL, USA).

\section{Results and Discussion}

\section{Rice and wheat yields}

The grain and straw yields of rice and wheat both crops after harvest were highest with treatment $100 \% \mathrm{NPK}+15 \mathrm{t} \mathrm{FYM} \mathrm{ha}^{-1}$ (Table 1). This treatment produced $44.98 \%$ and $53.84 \%$ higher rice yields and 45.07 and $53.43 \%$ higher wheat yields over $100 \%$ NPK application, respectively, and was significantly superior to all other fertilizers treatments. The pivotal role of soil microorganisms and enzymatic activities in transformation and availability of nutrient elements in soil is well documented (Nannipieri et al., 1990). It can also be due to improvement in soil physical conditions as a result of continuous FYM application, which provided congenial environment for plant growth and nutrient uptake (Tejada et al., 2009). These results are in conformity with the findings of Selvi et al., (2004) and Mishra et al., (2008). Application of $100 \% \mathrm{NPK}+\mathrm{Zn}$ was second highest by producing grain and straw yields of rice (33.71 and $32.80 \%$ ) and wheat, (30.00 and $49.31 \%$ ), in comparison to $100 \%$ NPK treatment, respectively. The significant positive response of $\mathrm{Zn}$ application with $100 \%$ NPK could be attributed to the development of $\mathrm{Zn}$ deficiency in soil due to continuous rice-wheat crops over the years, as reported earlier also by Ram (2000) and Varshney et al., (2008). Treatments having application of $100 \%$ NP and $100 \%$ NPK-S show significantly higher yields of both grain and straw in both crops as compared to control, because these two treatments receiving zinc as well as $100 \%$ NP and $100 \%$ NPK-S. Although zinc was not applied in treatment having 100and 50\% NPK. Reason behind the imbalanced fertilizer treatment of $100 \% \mathrm{~N}$ was at par with $100 \%$ NPK in rice and wheat yields may be ascribed to adequate availability of $\mathrm{P}$ and $\mathrm{K}$ in soil due to continuous addition of crop residues in the form of roots stubbles and leaf fall. These results suggested that application of FYM and $\mathrm{Zn}$ with $100 \%$ NPK are necessary for sustaining productivity in rice-wheat cropping system in Mollisols.

\section{Microbial population}

Application of $100 \% \mathrm{NPK}+15 \mathrm{t} \mathrm{FYM} \mathrm{ha}^{-1}$ recorded highest population of bacteria (15.19 and $18.22 \mathrm{cfu} \times 10^{8} \mathrm{~g}^{-1}$ soil) at surface soil of depth $0-15 \mathrm{~cm},\left(12.92\right.$ and $14.00 \mathrm{cfu} \times 10^{8} \mathrm{~g}^{-1}$ soil) at $15-30 \mathrm{~cm},\left(5.69\right.$ and $7.49 \mathrm{cfu} \times 10^{8} \mathrm{~g}^{-1}$ soil) at $30-45 \mathrm{~cm}$ and $\left(2.12\right.$ and $3.65 \mathrm{cfu} \times 10^{8}$ $\mathrm{g}^{-1}$ soil) at $45-60 \mathrm{~cm}$ in rice and wheat crops, respectively followed by $150 \%$ NPK treatment (Fig. 1). FYM incorporation along with $100 \%$ NPK fertilizers showed maximum and significantly higher fungi and actinomycetes population $\left(39.23 \mathrm{cfu} \times 10^{4} \mathrm{~g}^{-1}\right.$ soil and 49.17 cfu $\times 10^{5} \mathrm{~g}^{-1}$ soil $)$ after rice and $(52.29 \mathrm{cfu} \times$ $10^{4} \mathrm{~g}^{-1}$ soil and $53.13 \mathrm{cfu} \times 10^{5} \mathrm{~g}^{-1}$ soil) after wheat in surface soil, respectively (Fig. 2 and 3). Upadhyay et al., (2011) and Singh et al., (2012) also reported the similar results which might be attributed to the availability of adequate biomass as feed for the microbes. Decreasing trend in fungi and actinomycetes population was found with respect to soil depth. Balanced fertilizer treatment $(100 \%$ $\mathrm{NPK}+\mathrm{Zn}$ ) recorded significantly higher bacteria, fungi and actinomycetes compared to $100 \% \mathrm{~N}, 100 \% \mathrm{NP}$ and control treatments. Lower microbial population in soils after rice was observed in comparison to wheat. The $150 \%$ NPK was comparable to $100 \%$ NPK and $100 \% \mathrm{NPK}+\mathrm{Zn}$ in soil microbial population and suggests that supply of inorganic nutrients at higher than optimum 
level without organic manure cannot support microbial population in the soil. Sharma et al., 2016 suggested that the increase in microorganism numbers in response to chemical fertilizers may be attributed to a better nutrient status of soil and also reported that the effect was greater in the treatment where $50 \%$ substitution of $\mathrm{N}$ was made through FYM or wheat straw in rice. The treatment $100 \% \mathrm{NPK}+\mathrm{Zn}$ was statistically comparable with $100 \%$ NPK in mean counts of bacteria, fungi and actinomycetes after rice and wheat crops; however, these treatments gave significantly lower counts than $100 \%$ $\mathrm{NPK}+15 \mathrm{t} \mathrm{FYM} \mathrm{ha}{ }^{-1}$ indicating organic manure incorporation has greater positive effect on microbial population in the soil. Lowest microbial population was recorded in control and $100 \% \mathrm{~N}$. These results are in agreement with the findings of Jayathilake et al., (2006) and Sharma et al., (2010).

\section{Dehydrogenase activity}

The integrated use of $100 \%$ NPK along with $15 \mathrm{t} \mathrm{ha}^{-1}$ FYM showed maximum and significantly higher DHA values (353.61 $\mu \mathrm{g}$ TPF $\mathrm{g}^{-1} 24 \mathrm{~h}^{-1}$ in rice and $365.22 \mu \mathrm{g}$ TPF $\mathrm{g}^{-1}$ $24 \mathrm{~h}^{-1}$ in wheat) in surface as well as lower depths soils as compared to all other fertilizer treatments (Table 2). A relatively more pronounced effect of organic manure on soil enzyme activities in comparison to the inorganic fertilizers has also been reported earlier by Chu et al., (2007) and Romero et al., (2010). The increase in dehydrogenase enzyme activity is attributed to the availability of higher carbon substrates, being sole sources of carbon and energy for heterotrophs. Balanced use of fertilizers $(100 \% \mathrm{NPK}+\mathrm{Zn})$ gave significantly higher DHA values as compared to $150 \%$ NPK treatment but significantly lesser then $100 \%$ NPK+FYM treatment. This confirms that application of balanced fertilizers NPK maintained active pools of $\mathrm{C}$ and $\mathrm{N}$ in the soil surface layer due to increased plant biomass addition in these treatments. Similar results were also reported by Bhavani et al., (2017) and Gill et al., (2016).Similarly, 100\% NPK application recorded comparable values of DHA with $150 \%$ NPK in rice and slightly higher in wheat, which was significantly lower than 100\% NPK+FYM@15 t ha ${ }^{-1}$. Lowest values of DHA were observed in control and $100 \% \mathrm{~N}$ treatment after rice and wheat harvest. The decreased dehydrogenase activity under $100 \%$ $\mathrm{N}$ alone is associated with the redox potential of soil. The redox potential of the soil might have been increased due to accumulation of nitrate over the years following application of nitrogenous fertilizer, thereby decreasing dehydrogenase activity. These results are in accordance with Bhatt et al., (2016) and Mandal et al., (2007). In general, slightly higher values of DHA were recorded in soils after wheat as compared to soils after rice. The dehydrogenase activity (DHA) in soils after rice and wheat was highest under $100 \%$ NPK+FYM @ $15 \mathrm{t} \mathrm{ha}^{-1}$ treatment in all four depths. Upper surface $(0-15 \mathrm{~cm})$ soil has remarkably higher values of DHA after rice as well as wheat crop harvest in comparison to lower depths. The dehydrogenase activity in soil significantly increased with increasing NPK levels from $50 \%$ to $100 \%$. Imbalanced and inadequate application of fertilizers $(50 \%$ NPK, $100 \%$ NP and $100 \% \quad \mathrm{~N}$ ) caused significant decline in the dehydrogenase activity. The significantly lower dehydrogenase enzyme activity in soil with NPK(-S) treatment in comparison to $100 \%$ NPK could be viewed in line of the trend observed in microbial population and biomass due to a build-up of S deficiency in the soil as a result of continuous use of $S$-free fertilizers. Beneficial effects of $\mathrm{S}$ fertilization on the dehydrogenase enzyme activity in soil has also been reported by Niewiadomska et al., (2015), being an essential constituent of several amino acids and co-enzymes that play a role in microbial metabolism. 


\section{Phosphatase activity}

Irrespective of the different treatments, alkaline phosphatase enzyme activity in soil was more than acid phosphatase enzyme activity after harvest of both rice and wheat crops due to the alkaline soil condition (Eivazi and Tabatabai, 1977). Acid and alkaline phosphatase activities were significantly enhanced by NPK fertilizer application. In control it was 45.70 and $44.97 \mu \mathrm{g} \mathrm{PNP} \mathrm{g}{ }^{-1} \mathrm{~h}^{-1}$ as compared to 81.55 and $88.27 \mu \mathrm{g} \mathrm{PNP} \mathrm{g}^{-1}$ $\mathrm{h}^{-1}$, respectively in $100 \%$ NPK for rice (Table 3 and 4). After harvest of rice crop both acid and alkaline activities (99.42 and $120.24 \mu \mathrm{g}$ PNP $\mathrm{g}^{-1} \mathrm{~h}^{-1}$, respectively) were recorded maximum and significantly higher in $100 \%$ $\mathrm{NPK}+\mathrm{FYM} @ 15 \mathrm{t} \mathrm{ha}^{-1}$ treatment. Significantly higher activity of phosphatase enzyme in FYM applied treatment over other treatment could be attributed to additional supply of $\mathrm{N}$ and $\mathrm{C}$ substrates through applied FYM for supporting microbial activity. Bhatt et al., (2016) also reported that treatment with $100 \%$ NPK + 15 t FYM ha $^{-1}$ shows the highest acid and alkaline phosphatase activity in case of both rice and wheat crops. Balanced application of fertilizer $(100 \% \mathrm{NPK}+\mathrm{Zn})$ was 4.2 and 24.41per cent higher acid and alkaline phosphatase activities over treatment where $\mathrm{Zn}$ was not added along with $100 \%$ NPK. Mishra et al., (2008), Balanced fertilization supports higher plant biomass production and contributes greater return of organic residue in soil through leaf fall and root stubbles, which in turn promote the growth and activities of microorganisms. Both acid and alkaline phosphatase activities were decreased with the soil depths after harvest of both the crops. In case of wheat these both acid and alkaline phosphatase activities were also found highest (104.72 and $123.04 \mu \mathrm{g}$ PNP $\mathrm{g}^{-1} \mathrm{~h}^{-1}$, respectively) in FYM treated plot. Garg and Bahl (2008) also found similar increase in the alkaline phosphatase activity with combined application of organic manure and inorganic fertilizers. Lowest activity of phosphatase enzyme was recorded in control after harvest of both rice and wheat crops.

\section{Urease activity}

Application of 100\% NPK + FYM @ $15 \mathrm{t} \mathrm{ha}^{-1}$ recorded highest urease enzyme activity after rice and wheat $\left(7.94\right.$ and $8.14 \mathrm{mg}^{\text {urea }} \mathrm{g}^{-1} 24$ $\mathrm{h}^{-1}$, respectively) in surface $(0-15 \mathrm{~cm})$ soil while it was less in sub-surface soil and decreased continuously with the soil depth (Table 5). Urease activity being high in FYM amended treatment could be because to the continuous application of organic manure, which acts as a source of $\mathrm{C}$ and energy for heterotrophs and provides adequate nutrition for the growth of microorganisms and their function in terms of production of soil enzymes (Rai and Yadav, 2011).

Chhonkar and Tarafdar (1981) also found that activities of the soil enzymes were significantly and positively correlated with organic $\mathrm{C}$ and microbial population in the soil. Application of $100 \% \mathrm{NPK}+\mathrm{Zn}$ was at par with $150 \%$ NPK and gave significantly higher urease enzyme activity in soil over the imbalanced fertilizer treatments like 50\% NPK, $100 \% \mathrm{NP}$ and $100 \% \mathrm{~N}$ after harvest of both the crops. Minimum urease enzyme activity observed in control plot and $100 \% \mathrm{~N}$. Integrated use of FYM @ $15 \mathrm{t} \mathrm{ha}^{-1}$ in combination with $100 \%$ NPK causes 32.33 , 17.28 and 18.33 per cent more urease activity over $100 \%$ NPK, $150 \%$ NPK and 100\% NPK+Zn. $100 \%$ NPK without Zn treatment had 11.83 per cent less urease enzyme activity as compared to $100 \%$ NPK with $\mathrm{Zn}$. The favourable effects of increasing the levels of $\mathrm{N}$ on urease enzyme activity in the soil could be attributed to increase in microbial population as well as release of greater proportion of nitrogenous substances in root exudates that induce the urease enzyme activity (Elayaraja and Singarvel, 2011). 
Table.1 Rice and wheat yields

\begin{tabular}{|c|c|c|c|c|c|c|}
\hline \multirow[b]{2}{*}{ Treatments } & \multicolumn{3}{|c|}{ Rice } & \multicolumn{3}{|c|}{ Wheat } \\
\hline & $\begin{array}{l}\text { Grain } \\
\text { yield }\end{array}$ & $\begin{array}{c}\text { Straw } \\
\text { yield }\end{array}$ & $\begin{array}{l}\text { Total } \\
\text { yield }\end{array}$ & $\begin{array}{l}\text { Grain } \\
\text { yield }\end{array}$ & $\begin{array}{c}\text { Straw } \\
\text { yield }\end{array}$ & $\begin{array}{l}\text { Total } \\
\text { yield }\end{array}$ \\
\hline $50 \%$ NPK & 36.43 & 34.20 & 70.63 & 32.90 & 37.97 & 70.87 \\
\hline $100 \%$ NPK & 35.50 & 39.63 & 75.13 & 33.50 & 37.17 & 70.67 \\
\hline $150 \%$ NPK & 34.88 & 37.97 & 72.85 & 33.20 & 40.03 & 73.23 \\
\hline $100 \% \mathrm{NPK}+\mathrm{Zn}$ & 47.47 & 52.63 & 100.10 & 43.55 & 55.50 & 99.05 \\
\hline $100 \% \mathrm{NP}$ & 44.60 & 48.57 & 93.17 & 39.53 & 40.60 & 80.13 \\
\hline $100 \% \mathrm{~N}$ & 33.95 & 35.80 & 69.75 & 36.97 & 32.73 & 69.70 \\
\hline $100 \% \mathrm{NPK}+\mathrm{FYM}$ & 51.47 & 60.97 & 112.43 & 48.60 & 57.03 & 105.63 \\
\hline $100 \%$ NPK(-S) & 42.73 & 42.83 & 85.57 & 37.70 & 40.43 & 78.13 \\
\hline Control & 13.72 & 16.23 & 29.95 & 11.85 & 13.73 & 25.59 \\
\hline SEm \pm & 1.35 & 1.18 & 1.68 & 1.91 & 1.09 & 2.44 \\
\hline CD @ 5\% & 4.05 & 3.54 & 5.06 & 5.72 & 3.28 & 7.32 \\
\hline
\end{tabular}

Table.2 Effect of fertilizer application with different combinations of organic and inorganic sources on soil dehydrogenase activity ( $\mu \mathrm{g}$ TPF $24 \mathrm{~h}^{-1} \mathrm{~g}^{-1}$ soil)

\begin{tabular}{|c|c|c|c|c|c|c|c|c|}
\hline \multirow[b]{2}{*}{ Treatments } & \multicolumn{4}{|c|}{ Rice } & \multicolumn{4}{|c|}{ Wheat } \\
\hline & $\begin{array}{l}0-15 \\
\mathrm{~cm}\end{array}$ & $\begin{array}{l}15-30 \\
\mathrm{~cm}\end{array}$ & $\begin{array}{l}30-45 \\
\mathrm{~cm}\end{array}$ & $\begin{array}{l}45-60 \\
\mathrm{~cm}\end{array}$ & $\begin{array}{l}0-15 \\
\mathrm{~cm}\end{array}$ & $\begin{array}{l}15-30 \\
\mathrm{~cm}\end{array}$ & $\begin{array}{l}30-45 \\
\mathrm{~cm}\end{array}$ & $\begin{array}{l}45-60 \\
\mathrm{~cm}\end{array}$ \\
\hline $50 \%$ NPK & 145.15 & 90.67 & 60.10 & 26.02 & 181.88 & 92.93 & 61.45 & 27.99 \\
\hline $100 \%$ NPK & 291.02 & 116.19 & 76.63 & 43.69 & 291.41 & 119.11 & 81.43 & 47.38 \\
\hline $150 \%$ NPK & 294.00 & 120.48 & 81.37 & 42.64 & 297.37 & 131.00 & 86.39 & 49.10 \\
\hline $100 \% \mathrm{NPK}+\mathrm{Zn}$ & 312.64 & 117.13 & 74.65 & 45.29 & 327.02 & 126.51 & 83.50 & 52.25 \\
\hline $100 \% \mathrm{NP}$ & 143.77 & 91.13 & 67.78 & 38.08 & 171.83 & 97.14 & 74.21 & 45.07 \\
\hline $100 \% \mathrm{~N}$ & 120.57 & 87.34 & 54.11 & 32.45 & 142.15 & 95.47 & 71.22 & 40.91 \\
\hline $100 \% \mathrm{NPK}+\mathrm{FYM}$ & 353.61 & 150.67 & 91.48 & 54.12 & 365.22 & 155.90 & 99.09 & 59.17 \\
\hline $100 \%$ NPK(-S) & 148.39 & 94.57 & 64.09 & 33.63 & 160.58 & 98.31 & 74.24 & 41.53 \\
\hline Control & 115.78 & 72.63 & 40.56 & 20.84 & 137.11 & 82.46 & 46.46 & 28.00 \\
\hline SEm \pm & 1.11 & 0.49 & 0.72 & 0.70 & 1.19 & 1.42 & 0.53 & 0.46 \\
\hline CD@ $@ 5 \%$ & 3.33 & 1.47 & 2.16 & 2.10 & 3.58 & 4.28 & 1.59 & 1.38 \\
\hline
\end{tabular}


Table.3 Effect of fertilizer application with different combinations of organic and inorganic sources on soil acid phosphatase activity $\left(\mu \mathrm{g} \mathrm{PNP} \mathrm{h}{ }^{-1} \mathrm{~g}^{-1}\right.$ soil)

\begin{tabular}{|c|c|c|c|c|c|c|c|c|}
\hline \multirow[b]{2}{*}{ Treatments } & \multicolumn{4}{|c|}{ Rice } & \multicolumn{4}{|c|}{ Wheat } \\
\hline & $\begin{array}{c}0-15 \\
\mathrm{~cm}\end{array}$ & $\begin{array}{c}15-30 \\
\mathrm{~cm}\end{array}$ & $\begin{array}{c}30-45 \\
\mathrm{~cm}\end{array}$ & $\begin{array}{c}45-60 \\
\mathrm{~cm}\end{array}$ & $\begin{array}{c}\text { 0-15 } \\
\mathrm{cm}\end{array}$ & $\begin{array}{c}15-30 \\
\mathrm{~cm}\end{array}$ & $\begin{array}{c}30-45 \\
\mathrm{~cm}\end{array}$ & $\begin{array}{c}\text { 45-60 } \\
\mathrm{cm}\end{array}$ \\
\hline $50 \%$ NPK & 63.99 & 32.61 & 14.30 & 7.78 & 79.14 & 52.07 & 34.32 & 9.82 \\
\hline $100 \%$ NPK & 81.55 & 36.17 & 19.04 & 9.21 & 87.73 & 62.77 & 36.31 & 12.77 \\
\hline $150 \%$ NPK & 87.14 & 36.76 & 19.25 & 13.36 & 97.74 & 68.72 & 42.34 & 13.32 \\
\hline $100 \% \mathrm{NPK}+\mathrm{Zn}$ & 85.04 & 36.55 & 21.43 & 10.68 & 95.71 & 62.77 & 38.43 & 12.27 \\
\hline $100 \% \mathrm{NP}$ & 69.91 & 29.91 & 14.96 & 9.77 & 81.74 & 50.46 & 36.44 & 9.76 \\
\hline $100 \% \mathrm{~N}$ & 61.94 & 28.63 & 13.69 & 7.13 & 73.23 & 39.52 & 29.60 & 7.69 \\
\hline $100 \% \mathrm{NPK}+\mathrm{FYM}$ & 99.42 & 60.61 & 24.47 & 14.29 & 104.72 & 69.28 & 43.41 & 16.35 \\
\hline $100 \%$ NPK(-S) & 77.51 & 34.50 & 18.92 & 8.87 & 82.27 & 53.67 & 37.68 & 10.28 \\
\hline Control & 45.70 & 19.50 & 9.12 & 4.82 & 48.14 & 29.96 & 13.59 & 4.75 \\
\hline SEm \pm & 1.29 & 1.03 & 0.70 & 0.48 & 1.61 & 1.13 & 0.59 & 0.68 \\
\hline CD@ $9 \%$ & 3.87 & 3.09 & 2.11 & 1.44 & 4.84 & 3.40 & 1.78 & 2.03 \\
\hline
\end{tabular}

Table.4 Effect of fertilizer application with different combinations of organic and inorganic sources on soil alkaline phosphatase activity $\left(\mu \mathrm{g} \mathrm{PNP} \mathrm{h}^{-1} \mathrm{~g}^{-1}\right.$ soil)

\begin{tabular}{|c|c|c|c|c|c|c|c|c|}
\hline \multirow[b]{2}{*}{ Treatments } & \multicolumn{4}{|c|}{ Rice } & \multicolumn{4}{|c|}{ Wheat } \\
\hline & $\begin{array}{l}0-15 \\
\mathrm{~cm}\end{array}$ & $\begin{array}{l}15-30 \\
\mathrm{~cm}\end{array}$ & $\begin{array}{l}30-45 \\
\mathrm{~cm}\end{array}$ & $\begin{array}{l}45-60 \\
\mathrm{~cm}\end{array}$ & $\begin{array}{l}0-15 \\
\mathrm{~cm}\end{array}$ & $\begin{array}{l}15-30 \\
\mathrm{~cm}\end{array}$ & $\begin{array}{l}30-45 \\
\mathrm{~cm}\end{array}$ & $\begin{array}{l}45-60 \\
\mathrm{~cm}\end{array}$ \\
\hline $50 \%$ NPK & 77.26 & 31.60 & 21.99 & 11.56 & 94.22 & 67.80 & 46.17 & 16.40 \\
\hline $100 \%$ NPK & 88.27 & 40.87 & 21.65 & 13.65 & 103.10 & 75.61 & 49.44 & 16.88 \\
\hline $150 \%$ NPK & 110.30 & 44.98 & 21.08 & 12.21 & 112.22 & 77.53 & 59.91 & 19.29 \\
\hline $100 \% \mathrm{NPK}+\mathrm{Zn}$ & 109.82 & 43.64 & 18.34 & 10.72 & 106.81 & 75.16 & 49.08 & 17.53 \\
\hline $100 \% \mathrm{NP}$ & 83.58 & 35.00 & 21.37 & 9.91 & 94.51 & 68.24 & 43.91 & 13.66 \\
\hline $100 \% \mathrm{~N}$ & 81.32 & 30.36 & 16.04 & 9.51 & 81.74 & 62.80 & 38.49 & 9.50 \\
\hline $100 \% \mathrm{NPK}+\mathrm{FYM}$ & 120.24 & 52.59 & 26.01 & 14.21 & 123.04 & 89.45 & 58.27 & 20.66 \\
\hline $100 \%$ NPK(-S) & 85.78 & 39.72 & 22.12 & 10.39 & 97.76 & 72.79 & 47.31 & 15.40 \\
\hline Control & 44.97 & 18.61 & 15.07 & 4.10 & 60.96 & 43.79 & 21.91 & 7.14 \\
\hline SEm \pm & 1.52 & 1.73 & 0.81 & 0.62 & 1.05 & 1.15 & 0.98 & 0.57 \\
\hline CD@ $5 \%$ & 4.54 & 5.19 & 2.42 & 1.86 & 3.14 & 3.45 & 2.95 & 1.71 \\
\hline
\end{tabular}


Table.5 Effect of fertilizer application with different combinations of organic and inorganic sources on soil urease activity (mg urea $\mathrm{g}^{-1}$ soil $24 \mathrm{~h}^{-1}$ )

\begin{tabular}{|c|c|c|c|c|c|c|c|c|}
\hline & \multicolumn{4}{|c|}{ Rice } & \multicolumn{4}{|c|}{ Wheat } \\
\hline Treatments & $\begin{array}{l}0-15 \\
\text { cm }\end{array}$ & $\begin{array}{l}15-30 \\
\mathrm{~cm}\end{array}$ & $\begin{array}{l}30-45 \\
\mathrm{~cm}\end{array}$ & $\begin{array}{l}45-60 \\
\mathrm{~cm}\end{array}$ & $\begin{array}{l}0-15 \\
\text { cm }\end{array}$ & $\begin{array}{l}15-30 \\
\mathrm{~cm}\end{array}$ & $\begin{array}{l}30-45 \\
\mathrm{~cm}\end{array}$ & $\begin{array}{l}45-60 \\
\mathrm{~cm}\end{array}$ \\
\hline $50 \%$ NPK & 4.90 & 3.83 & 1.83 & 0.89 & 5.62 & 4.01 & 2.25 & 1.13 \\
\hline $100 \%$ NPK & 6.00 & 4.92 & 2.23 & 1.19 & 6.69 & 5.42 & 2.75 & 1.44 \\
\hline $150 \%$ NPK & 6.77 & 5.29 & 2.73 & 1.81 & 6.68 & 5.25 & 3.23 & 2.16 \\
\hline $100 \% \mathrm{NPK}+\mathrm{Zn}$ & 6.71 & 4.82 & 2.59 & 1.86 & 6.82 & 5.34 & 2.80 & 2.18 \\
\hline $100 \% \mathrm{NP}$ & 5.00 & 3.29 & 1.93 & 0.86 & 5.70 & 3.79 & 2.36 & 1.37 \\
\hline $100 \% \mathrm{~N}$ & 4.40 & 2.75 & 1.69 & 0.74 & 5.12 & 3.29 & 2.05 & 1.12 \\
\hline $100 \% \mathrm{NPK}+\mathrm{FYM}$ & 7.94 & 5.82 & 3.06 & 2.14 & 8.14 & 5.45 & 3.38 & 2.30 \\
\hline $100 \%$ NPK(-S) & 5.09 & 3.75 & 1.91 & 1.11 & 4.94 & 3.46 & 2.07 & 1.25 \\
\hline Control & 3.97 & 2.57 & 1.53 & 0.53 & 4.19 & 2.48 & 1.74 & 0.79 \\
\hline SEm \pm & 0.43 & 0.81 & 0.37 & 0.46 & 0.78 & 0.73 & 0.56 & 0.58 \\
\hline CD@ $0 \%$ & 0.13 & 0.24 & 0.11 & 0.14 & 0.23 & 0.22 & 0.17 & 0.17 \\
\hline
\end{tabular}

Table.6 Effect of fertilizer application with different combinations of organic and inorganic sources on soil microbial biomass carbon $\left(\mu \mathrm{g} \mathrm{g}^{-1}\right.$ soil)

\begin{tabular}{|c|c|c|c|c|c|c|c|c|}
\hline \multirow[b]{2}{*}{ Treatments } & \multicolumn{4}{|c|}{ Rice } & \multicolumn{4}{|c|}{ Wheat } \\
\hline & $\begin{array}{l}0-15 \\
\mathrm{~cm}\end{array}$ & $\begin{array}{l}15-30 \\
\mathrm{~cm}\end{array}$ & $\begin{array}{l}30-45 \\
\mathrm{~cm}\end{array}$ & $\begin{array}{l}45-60 \\
\mathrm{~cm}\end{array}$ & $\begin{array}{l}0-15 \\
\mathrm{~cm}\end{array}$ & $\begin{array}{l}15-30 \\
\mathrm{~cm}\end{array}$ & $\begin{array}{l}30-45 \\
\mathrm{~cm}\end{array}$ & $\begin{array}{l}45-60 \\
\mathrm{~cm}\end{array}$ \\
\hline $50 \%$ NPK & 252.70 & 135.67 & 66.11 & 15.50 & 265.17 & 142.22 & 70.47 & 15.73 \\
\hline $100 \%$ NPK & 331.56 & 157.13 & 77.20 & 28.62 & 333.79 & 175.91 & 85.45 & 30.20 \\
\hline $150 \%$ NPK & 343.31 & 167.43 & 88.53 & 42.26 & 345.70 & 183.04 & 101.74 & 44.77 \\
\hline $100 \% \mathrm{NPK}+\mathrm{Zn}$ & 336.18 & 162.45 & 81.56 & 34.38 & 347.89 & 183.12 & 93.62 & 43.14 \\
\hline $100 \% \mathrm{NP}$ & 229.42 & 123.77 & 51.22 & 16.54 & 245.44 & 131.53 & 59.85 & 17.07 \\
\hline $100 \% \mathrm{~N}$ & 220.96 & 112.96 & 41.68 & 12.99 & 233.29 & 121.00 & 53.39 & 15.26 \\
\hline $100 \% \mathrm{NPK}+\mathrm{FYM}$ & 413.36 & 193.50 & 100.11 & 66.41 & 435.93 & 235.54 & 142.64 & 82.41 \\
\hline $100 \%$ NPK(-S) & 266.77 & 134.94 & 70.20 & 26.66 & 282.21 & 147.56 & 83.78 & 31.86 \\
\hline Control & 212.70 & 107.50 & 32.30 & 9.99 & 218.58 & 111.07 & 43.55 & 10.30 \\
\hline SEm \pm & 0.81 & 1.25 & 1.07 & 0.92 & 4.17 & 2.23 & 0.75 & 0.79 \\
\hline CD@ $@ 5 \%$ & 2.45 & 3.77 & 3.21 & 2.77 & 12.51 & 6.70 & 2.27 & 2.39 \\
\hline
\end{tabular}


Figure.1 Effect of fertilizer application with different combinations of organic and inorganic sources on soil bacterial population $\left(\times 10^{8} \mathrm{cfu} \mathrm{g}^{-1}\right.$ dry soil $)$

Rice

Figure.2 Effect of fertilizer application with different combinations of organic and inorganic sources on soil fungal population $\left(\times 10^{4} \mathrm{cfu} \mathrm{g}^{-1}\right.$ dry soil $)$

Rice


Figure.3 Effect of fertilizer application with different combinations of organic and inorganic sources on soil actinomycetes population $\left(\times 10^{5} \mathrm{cfu} \mathrm{g}^{-1}\right.$ dry soil $)$

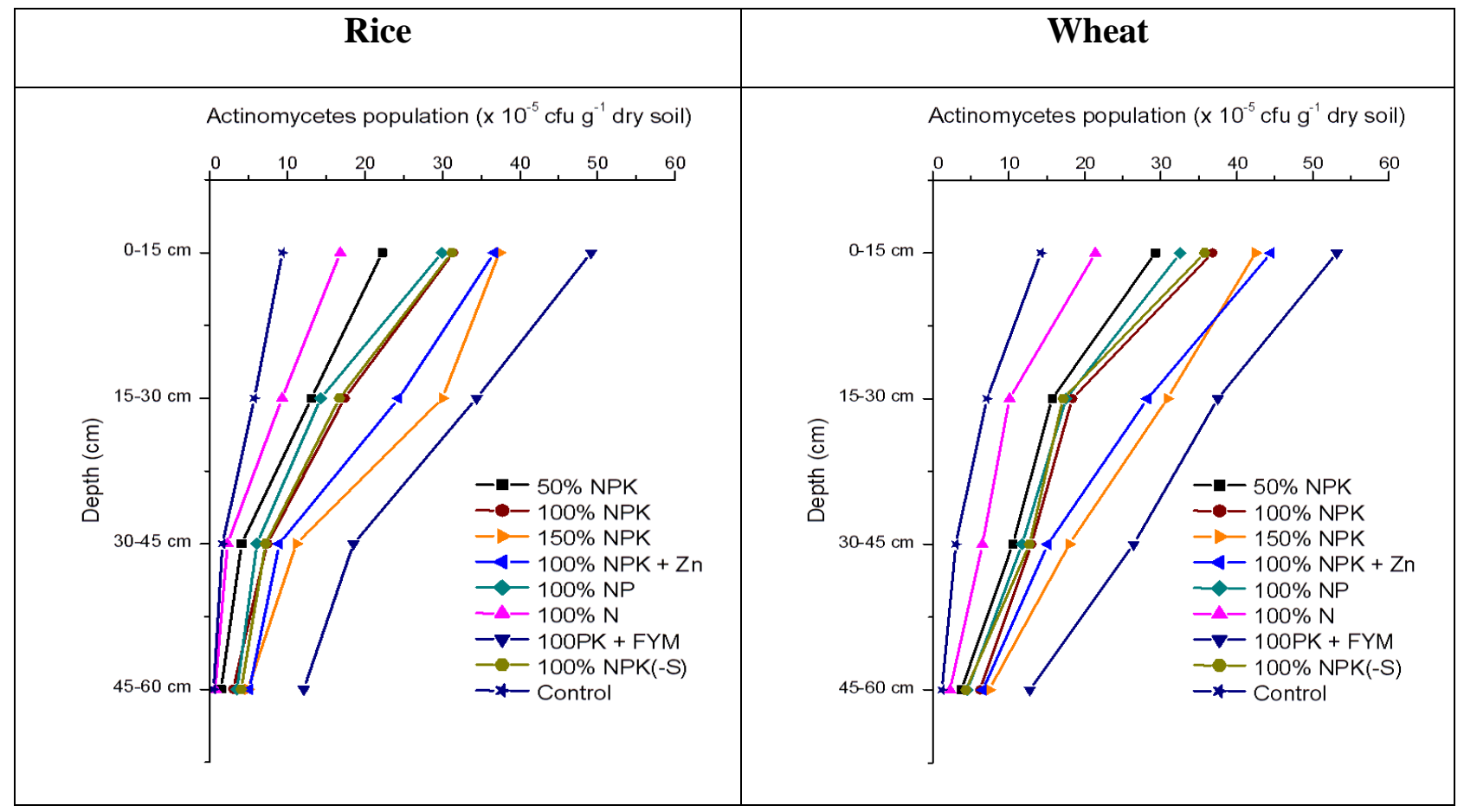

\section{Soil microbial biomass carbon}

Soil microbial biomass Carbon (SMBC) reflects the response of nutrient management on microbial biomass. The treatment with combination of organic and mineral source of nutrients registered the maximum (413.36 and $435.93 \mu \mathrm{g} \mathrm{g}^{-1}$ soil, respectively) and significantly higher content of SMBC in surface soil after harvest of both rice and wheat, sub-surface soil also showed same trend but the content of SMBC reduced in the deeper soil (Table 6). Treatment with $100 \%$ NPK in addition with FYM again showing the best result among all the treatment may be due to the catalytic effect of FYM in stimulating microbial growth, resulting in higher microbial biomass Vineela et al., (2008) also reported significant enhancement in the soil microbial biomass $\mathrm{C}$ due to NPK and FYM application in Vertisols at Coimbatore. Treatments of $100 \%$ and $150 \%$ NPK were at par in soil microbial biomass C after wheat; however, a reduced dose of chemical fertilizers $(50 \% \mathrm{NPK})$ resulted in significantly lower soil microbial biomass $\mathrm{C}$ than $100 \%$ NPK. Similarly, continuous use of $100 \% \mathrm{~N}, 100 \% \mathrm{NP}$ and $100 \%$ NPK(-S) resulted in significantly low soil microbial biomass $\mathrm{C}$ than $100 \%$ NPK possibly due to inadequate and imbalanced supply of the nutrients for microbial utilization in soil. Minimum SMBC content was registered in control plot after both the crops.

\section{References}

Basak, B.B., Biswas, D.R. and Rattan, R.K. (2012). Comparative eff ectiveness of value added manures on crop productivity, soil mineral nitrogen and soil carbon pools under maize-wheat cropping system in an Inceptisol. J. Indian Soc. Soil Sci. 60: 288-298.

Bhatt, B., Chandra, R., Ram, S. and Pareek, N. (2016). Longterm effects of fertilization and manuring on productivity and soil 
biological properties under rice (Oryza sativa)-wheat (Triticum aestivum) sequence in Mollisols. Archives Agr. Soil Sci. DOI:

10.1080/03650340.2015.1125471.

Bhavani, S., Shaker, K. C., Jayasree, G. and Padmaja, B. (2017). Effects of long term application of inorganic and organic fertilizers on soil biological properties of rice. J. Pharma. Phytoche. 6(5): 11071110.

Cassida, L.E., Klein, D.A. and Santoro J. (1964). Soil dehydrogenase activity. Soil Science. 98: 371-376.

Chhonkar, P.K. and Tarafdar, J.C. (1981). Characteristics and location of phosphatase in soil plant system. J. Indian Soc. Soil Sci. 29: 215-219.

Chu, H., Lin, X., Fujii, T., Morimoto, S., Yagi, K., Hu, J. and Zhang, J. (2007). Soil microbial biomass, dehydrogenase activity, bacterial community structure in response to long-term fertilizer management. Soil Biol. Biochem. 39: 2971-2976.

Deshpande, S.B., Fehrenbacher, J.B. and Ray, B.W. (1971). Mollisols of Tarai region of Uttar Pradesh, Northern India, Genesis and classification. Geoderma. 6:195-201.

Duxbury, J. M., Abrol, I. P., Gupta, R. K. and Bronson, K. (2000). Analysis of longterm soil fertility experiments with ricewheat rotation in South Asia. In "Long-Term Soil Fertility Experiments in Rice-Wheat Cropping System". Eds. I P Abrol, K Bronson, J M Duxbury and R K Gupta pp. vii-xxii. Rice-Wheat Consortium Res. Ser. No. 6, Rice-Wheat Consortium for the Indo-Gangetic Plains, New Delhi, India

Eivazi, F. and Tabatabai, M.A. (1977). Phosphatases in soils. Soil Biol. Biochem. 9:167-172.

Elayaraja, D. and Singarvel, R. (2011). In fluence of organics and various levels of NPK on the soil nutrient availability, enzyme activity and yield of groundnut in coastal sandy soil. J. Indian Soc. Soil Sci. 59:300-303.
Garg, S. and Bahl, G.S. (2008). Phosphorus availability to maize as influenced by organic manures and fertilizer $P$ associated phosphatase activity in soils. Bioresour Technol. 99: 5773-5777.

Gaur, A.C. (1990). Phosphate solubilizing microorganisms as biofertilizers. Omega Scientific Publishers, New Delhi, India.

Gill, G. K., Gosal, S.K. and Sharma, S. (2016). Microbial activities and soil health in rice rhizosphere as affected by long term integrated use of organic and inorganic fertilizers. Int. J. Curr. Microbiol. Appl. Sci. 5(5): 568-580.

Gomez, K.A. and Gomez, A.A. (1984). Statistical procedures for agricultural research. New Delhi: John Wiley and Sons.

Jayathilake, P.K.S., Reddy, I.P., Srihari, D. and Reddy, K.R. (2006). Productivity and soil fertility status as influenced by integrated use of n-fixing biofertilizers, organic manures and inorganic fertilizers in onion. J. Agrl. Sci., 2(1): 46-58.

Jenkinson, D.S. and Powlson, D.S. (1976). The effect of biological treatments on metabolism in soil. V. A method for measuring soil biomass. Soil Biol. Biochem. 8:209-213.

Ladha, J. K., Dawe, D., Pathak, H., Padre, A. T., Yadav, R. L., Singh, B., Singh, Y., Singh, Y., Singh, P. and Kundu, A. L. (2003). How extensive are yield declines in long-term rice-wheat experiments in Asia? Field Crops Res.,81:159-180.

Ladha, J. K., Fisher, K. S., Hossain, M., Hobbs, P. R. and Hardy, B. (2000). Improving the productivity and sustainability of ricewheat systems of the Indo-Gangetic Plains: A synthesis of NARS - IRRI partnership research. Pp 1-31, Discussion paper no. 40. IRRI, Los Banos, Philippines

Mandal, B.K., Majumder, B., Bandyopadhyay, P.K., Hazra, G.C., Gangopadhyay, A., Samantaray, R.N., Mishra, A.K., Chaudhury, J., Saha, M.N. and Kundu, S. (2007). The potential of cropping systems and soil amendments for carbon 
sequestration in soils under long-term experiments in subtropical India. Global Change Biol., 13: 357-369.

Manna, M. C., Swarup, A., Wanjari, R. H., Ravankar, H. N., Mishra, B., Saha, M. N., Singh, Y. V., Sahi, D. K. and Sarap, P. A. (2005). Long-term effect of fertilizer and manure application on soil organic carbon storage, soil quality and yield sustainability under sub-humid and semiarid tropical India. Field Crops Res., 93:264-280.

Mishra, B., Sharma, A., Singh, S.K., Pramod, J. and Singh, B.P. (2008). Influence of continuous application of amendments to maizewheat cropping sequence on dynamics of microbial biomass in Alfisols of Jharkhand. J. Indian Soc. Soil Sci. 56:71- 75 .

Nannipieri, P., Ceccanti, B. and Grego, S. (1990). Ecological significance of biological activity in soil. In: Bollag, GM, Stotzky, G, editors. Soil biochemistry. New York (NY): Marcel Dekker; 6: 293 355.

Niewiadomska, A., Barog, P., Klaudia, B. K. and Wolna-Maruwka, A. (2015). The effect of sulphur and potassium fertilisation on the nitrogenase and microbial activity in soil under broad bean (Vicia faba L.) cultivation. Fresenius Environ. Bull. 24:723-732.

Patil, R.B. and Puranik, R.B. (2001). Microbial biomass $\mathrm{C}$ and $\mathrm{N}$ as influenced by cropping systems and nutrient management. PKV Res. J. 25:73-77.

Prasad, R. (2005). Rice-wheat cropping system. Adv. Agron., 86:285-339

Rai, T.N. and Yadav, J. (2011). In fluence of inorganic and organic nutrient sources on soil enzyme activities. J. Indian Soc. Soil Sci. 59: 54-59.

Ram, M., Davari, M. and Sharma, S. N. (2011). Organic farming of rice (Oryza sativa L.) - wheat (Triticum aestivum L.) cropping system: a review. Int. J. Agron. Plant Prod., 2 (3): 114-134.

Ram, N. (2000). Long-term eff ect of fertilizers on rice-wheat-cowpea productivity and soil properties in a Mollisols. In: Abrol, IP, Bronson, KF, Duxbury, JM, Gupta, RK, editors. Long-term fertility experiments in rice wheat cropping systems. Rice wheat consortium paper series 6. New Delhi: Rice-Wheat Consortium of the Indo-Gangetic Plains. 50-55.

Ram, N. 1995. Long term eff ect of fertilizers on crop production and soil properties in a Mollisol. Pantnagar: Experiment Station, G.B. Pant University of Agriculture and Technology. Tech. Res. Bull. 124:36.

Ram, S., Singh, V. and and Sirari, P. (2015). Effects of 41 Years of Application of Inorganic Fertilizers and Farm Yard Manure on Crop Yields, Soil Quality, and Sustainable Yield Index under a RiceWheat Cropping System on Mollisols of North India. Comm. Soil Sci. Pl. Anal. 47(2): 179-193.

Romero, E., Fernández-Bayo, J., Díaz, J. and Nogales, R. (2010). Enzyme activities and diuron persistence in soil amended with vermicompost derived from spent grape marc and treated with urea. Appl. Soil Ecol. 44: 198-204.

Selvi, D., Santhy, P., Dakshinamoorthy, M. and Maheshwari, M. (2004). Microbial population and biomass in rhizosphere as influenced by continuous intensive cultivation and fertilization in inceptisol. J. Indian Soc. Soil Sci. 52:254-257.

Shah, Z., Ahmad, R. and Rahman, H. U. (2011). Sustaining rice-wheat system through management of legumes I: effect of green manure legumes on rice yield and soil quality. Pak. J. Bot., 43:15691574

Sharma, S. A., Kumar, R., Rana, S. S., Guleria, G. and Negi, S.C. (2016). Effect of LongTerm Integrated Plant Nutrition System (Ipns) in Rice-Wheat Sequence on Soil Biological Health. 3(7): 21-34.

Sharma, S. Chander, G. and Verma, T.S. (2010). Soil microbiological and chemical changes in rice-wheat cropping system at Palampur (Himanchal Pradesh) after 
twelve years of Lantana camera L. residue incorporation. J. Trop. Agric., 48(2): 64-67.

Singh, A., Singh, V.K., Chandra, R. and Srivastava, P.C. (2012). Effect of integrated nutrient management on pigeon pea based intercropping system and soil properties in mollisols of the tarai region. J. Ind. Soc. Soil Sci., 60(1): 34-38.

Tabatabai, M.A. (1982). Soil enzymes. In: Page, AL, Miller, RH, Keeney, DR, editors. Methods of soil analysis, part 2, chemical and microbiological properties. Madison (WI): Soil Sci. Soc. America. 903-947.

Tabatabai, M.A. and Bremner, J.M. (1969). Use of p-nitrophenyl phosphate for assay of soil phosphatase activity. Soil Biol. Biochem. 1: 301-307.

Tejada, M., Hernandez, M.T. and Garcia, C. (2009). Soil restoration using composted plant residues: eff ects on soil properties. Soil Tillage Res. 102:109-117.

Timsinia, J., and Connor, D.J. (2001). Productivity and management of ricewheat systems: Issues and challenges. Field Crops Res. 69:93-132.

Upadhyay, V. B., Jain, V., Vishwakarma, S.K. and Kumhar, A. K. (2011). Production potential, soil health water productivity and economics of rice based cropping system under different nutrient source. Ind. J. Agro., 56(4); 311-316.
Vance, E.D., Brookes, P.C. and Jenkinson, D.S. (1987). An extraction method for measuring soil microbial biomass $\mathrm{C}$. Soil Biol Biochem. 19:703-707.

Varshney, R., Singh, S.K. and Srivastava, P.C. (2008). Frequency and rates of zinc application under hybrid rice -wheat sequence in a Mollisol of Uttarakhand. J Indian Soc Soil Sci. 56: 92-98.

Vineela, C., Wani, S.P., Srinivasarao, C.H., Padmaja, B. and Vittal, K.P.R. (2008). Microbial properties of soils as affected by cropping and nutrient management practices in several long-term manurial experiments in the semi-arid tropics of India. Appl Soil Ecol. 40: 165-173.

Wollum, A.G. (1982). Cultural methods for soil microorganisms. In: Page, AL, Miller, RH, Keeney, DR, editors. Methods of soil analysis. Part 2. Chemical and microbiological properties. Agronomy monograph No. 9. Madison (WI): ASA and SSSA; 781-814.

Yadav, D. S. and Kumar, A. (2009). Long-term effect of nutrient management on soil health and productivity of rice (Oryza Sativa)-wheat (Triticum Aestivum) system. Indian J Agron., 54:15-23.

Yadav, R. L., Dwivedi, B. S. and Pandey, P. S. (2000). Rice-wheat cropping system: assessment of sustainability under green manuring and chemical fertilizer inputs. Field Crops Res., 65: 15-30.

\section{How to cite this article:}

Vineet Kumar, Shri Ram and Ramesh Chandra. 2019. Crop Productivity and Soil Biological Properties Influenced by Long Term Application of Mineral Fertilizers and Manures under Rice-Wheat Sequence on Mollisols of Northern India. Int.J.Curr.Microbiol.App.Sci. 8(09): 299-312. doi: https://doi.org/10.20546/ijcmas.2019.809.036 